\title{
PRODUK JASA DOMPET DHUAFA: BERZAKAT TANPA KONTAK FISIK MELALUI WEBSITE
}

\author{
Aditya Nurrohma \\ STID Al-Hadid, Surabaya \\ adityanurrohma.an@gmail.com
}

\begin{abstract}
Abstrak: Adanya pandemi Covid-19 menjadikan masyarakat dibatasi untuk berinteraksi secara langsung demi memutus mata rantai penularan Covid-19, pun dalam hal sedekah, jika ditunaikan secara langsung bisa berpotensi terpapar virus Covid-19. Salah satu layanan zakat yang bisa digunakan di masa pandemi ialah website dompetdhuafa.org. Layanan zakat online yang ada sebelum pandemi ini telah mendapat bermacam penghargaan dan memiliki fitur yang cukup beragam untuk memenuhi kebutuhan muzaki tanpa kontak fisik. Tujuan studi ini untuk mendeskripsikan layanan zakat online pada website dompetdhuafa.org dengan perspektif teori pemasaran jasa oleh Christopher Lovelock. Studi ini menggunakan metode kualitatif, dengan pengumpulan data menggunakan teknik dokumentasi. Hasil studi ini menunjukkanbahwa Dompet Dhuafa memiliki produk inti berupa kemudahan penyaluran zakat melalui layanan zakat online pada website dompetdhuafa.org. Kemudian dalam rangka menunjang produk inti tersebut, Dompet Dhuafa memberikan layanan-layanan yang terbagi menjadi 8 kelompok yang terdiri dari informasi pembayaran zakat sampai dengan informasi Islam, pemesanan ketika akan berzakat yang mudah, penagihan jumlah zakat yang akurat, konsultasi selama mengakses website yang cepat karena secara online, keramahan pada berbagai layanan dan kemudahan mengakses website, pengamanan data diri muzaki, dan pengecualian berupa layanan pengaduan.
\end{abstract}

Kata Kunci: layanan zakat online, produk jasa, Dompet Dhuafa

Dompet Dhuafa Online Service: Doing Zakah Without Physical Contact. Abstract: Covid-19 pandemic has limited people from interacting directly for breaking the chain of Covid-19 transmission. Even, in the case of doing alms directly, people could potentially be exposed to the Covid-19 virus. One of online zakah services which can be used during this pandemic is the website of dompetdhuafa.org. It has received many awards and possesses various features to fulfil the needs of muzakki without physical contact. This study aims to describe online zakah service of dompetdhuafa.org by applying Christopher Lovelock's service marketing theory perspective. It uses descriptive qualitative methods, with documentation as data collecting. It indicates that Dompet Dhuafa has a core product in the form of zakah distribution facility through its online service of dompetdhuafa.org. then in order to support this core product, Dompet Dhuafa provides services classified into 8 features consisting of information on zakah payment to Islamic information, easy order when doing zakah, billing an accurate amount of zakah, fast online website accessing consultation, hospitality and easy website access, muzakki's personal data security, and exception in the form of complaint service.

Key words: online zakah service, service product, Dompet Dhuafa 


\section{Pendahuluan}

Suatu produk jasa menjadi hal yang perlu diperhatikan oleh penyedia jasa, termasuk di dalamnya terdapat produk inti dan layanan tambahan. Hal tersebut menjadi penting karena mendukung suatu produk bisa diterima oleh masyarakat atau tidak. Dimana produk inti memberikan solusi terhadap kebutuhan pasar, sedangkan layanan tambahan diperlukan untuk melengkapi produk inti dengan memberikan bantuan penggunaan produk inti dan juga menambah nilai lebih terhadap produk inti bagi pelanggan. Dengan begitu, pelanggan tidak akan kecewa terhadap pembelian tertentu karena adanya produk inti yang solutif dan layanan tambahan yang mempermudah serta mendukung. ${ }^{1}$

Demikian juga pada lembaga yang menerima dana dari umat yang salah satu pemberian dananya berasal dari muzaki, pihak lembaga harus berupaya membuat muzaki puas terhadap lembaga sehingga dana yang diperoleh lembaga akan meningkat. ${ }^{2}$ Dimana kualitas pelayanan (jasa) berpengaruh signifikan terhadap tingkat kepuasan muzaki dan kepuasan muzaki tersebut akan berpengaruh terhadap tingkat loyalitas muzaki. $^{3}$ Pada studi lain, menunjukkan bahwa kualitas layanan berpengaruh secara langsung dan signifikan terhadap keputusan

${ }^{1}$ Christopher Lovelock, Jochen Wirtz, dan Jacky Mussry, Pemasaran Jasa Manusia, Teknologi, Strategi, Jilid 1, Edisi ketujuh (Jakarta: Erlangga, 2010), 100.

2 Karebet Gunawan, "Pelayanan Lembaga Zakat Untuk Meningkatkan Kepuasan Muzakki", Jurnal ZIZWAF 04, no.02 (2017): 300. https://dx.doi.org/10.21043/ziswaf.v4i2.3047

3 Pengaruh Kualitas Pelayanan Lembaga Amil Zakat (LAZ) Terhadap Kepuasan dan Loyalitas Muzakki (Studi Kasus LAZ PKPU Yoyakarta)", Jurnal Aplikasi Bisnis dan Manajemen 03, no.01 (2017): 59. https://doi.org/10.17358/jabm.31.59 muzaki dalam berzakat profesi. ${ }^{4}$ Maka, menunjukkan bahwa suatu lembaga khususnya lembaga penghimpun dana umat yang menawarkan produk jasa dalam rangka menghimpun dana zakat perlu memperhatikan layanan yang diberikan, karena ketika layanan baik maka akan berpengaruh terhadap keputusan muzaki dalam berzakat.

Jika jasa merupakan suatu aktivitas ekonomi yang ditawarkan dari satu pihak kepada pihak lain dengan jangka waktu tertentu dan dalam bentuk kegiatan yang bisa mendatangkan hasil yang diinginkan, dengan karakteristiknya tidak berwujud, tidak terpisah, bervariasi, dan tidak tahan lama. ${ }^{5}$ Serta pemasaran jasa dalam sektor swasta nirlaba dapat dijumpai pada yayasan sosial, museum, sekolah, LBH, LSM, lembaga keagamaan, dan lain-lain. ${ }^{6}$ Maka layanan penghimpunan zakat tergolong dalam produk jasa karena memberikan pelayanan kepada muzaki yang ingin menyalurkan zakatnya supaya dikelola dan dialokasikan untuk program-program sosial keagamaan. Dengan demikian, lembaga penghimpun dana zakat memerlukan produk inti yang didukung oleh layanan tambahan

${ }^{4}$ Andi Martina Kamaruddin, Zamruddin Hasid, dan Isna Yuningsih, "Faktor-Faktor yang Mempengaruhi Keputusan berzakat Profesi dan Loyalitas Muzakki terhadap LAZ Rumah Zakat Kota Samarida", Jurnal Eksekutive 12, no.2 (2015): 284 https://jurnal.ibmt.ac.id/index.php/jeksekutif/ar ticle/download/97/96

${ }^{5}$ Lovelock, Pemasaran Jasa Manusia, Teknologi, Strategi, Jilid 1, Edisi ketujuh, 39.

6 Fandy Tjiptono, Strategi Pemasaran, Edisi 4 (Yogyakarta: Andi, 2015), 265. 
sebagaimana konsep Christopher Lovelock, Jochen Wirtz, dan Jacky Mussry. ${ }^{7}$

Saat ini di seluruh belahan dunia sedang mengalami fenomena pandemi Covid-19 atau dikenal dengan virus corona. Pandemi sendiri merupakan epidemi yang menyebar ke beberapa negara atau benua dan umumnya menjangkit banyak orang. ${ }^{8}$ Demikian juga dengan Indonesia, juga dilanda pandemi Covid-19. ${ }^{9}$ Pandemi ini menyebabkan banyaknya perubahan aktivitas masyarakat menjadi serba online. Hal tersebut dilakukan demi meminimalisir kontak fisik untuk memutus mata rantai penularan Covid-19. Himbauan social distancing, di rumah saja, hingga PSBB menyebabkan banyak orang segera menyesuaikan diri dalam berbagai aspek, termasuk dalam hal sedekah, masyarakat sudah seharusnya beradaptasi dengan new normal yaitu dengan membayar zakat secara online. ${ }^{10}$

Mekanisme pembayaran zakat secara online dipandang paling solutif bagi para OPZ (Organisasi Pengelola Zakat) dalam menghimpun dana zakat masyarakat. Selain mengurangi kontak fisik, sistem transaksi online juga mengurangi kontak dengan uang yang berpotensi menjadi media penularan

\footnotetext{
${ }^{7}$ Lovelock, Pemasaran Jasa Manusia, Teknologi, Strategi, Jilid 1, Edisi ketujuh, 101.

8 Theresia Vania Radhitya, Nunung Nurwati, dan Maulana Irfan, "Dampak Pandemi Covid-19 Terhadap Kekerasan Dalam Rumah Tangga", Jurnal Kolaborasi Resolusi Konflik Vo.2, no.2 (2020): 111.

9 Rizki Nurislaminingsih, "Layanan Pengetahuan Tentang Covid-19 di Lembaga Informasi", Jurnal Tik IImeu Vol.4, no.1 (2020): 20.

10 Forum Zakat, "Strategi Zakat Online di Tengah Pandemi", https://forumzakat.org/strategi-zakatonline-di-tengah-pandemi-harzolnas/, 15 November 2015. (diakses tanggal 15 November, 2020)

11 Ibid.,
}

virus karena sering berpindah tangan. ${ }^{11}$ Sehingga penting bagi lembaga yang menghimpun dana dari umat untuk menerapkan strategi digital dalam menghimpun dana supaya lembaga tidak mengalami penurunan penghimpunan dana dan tetap bisa menjaga keberlangsungan operasional. ${ }^{12}$

Dari kondisi pandemi yang mengharuskan masyarakat membayar zakat secara online maka bisa memanfaatkan salah satu layanan zakat online yang dimiliki oleh Dompet Dhuafa yang merupakan lembaga filantropi Islam yang berkhidmat dalam pemberdayaan kaum duafa, ${ }^{13}$ serta termasuk lembaga nirlaba. ${ }^{14}$ Layanan zakat online dompet dhuafa yang menarik untuk dikaji adalah website dompetdhuafa.org karena layanan zakat yang telah ada sejak sebelum pandemi ini makin relevan digunakan karena memiliki sejumlah layanan yang dapat diperoleh muzaki dengan tetap mengedepankan protokol kesehatan yaitu tanpa perlu keluar rumah dan tentunya tanpa kontak fisik.

Apalagi pada website Dompet Dhuafa terdapat banyak informasi yang bermanfaat untuk muzaki termasuk salah satunya adalah kegiatan sosial membantu masyarakat yang

12 Lida Puspaningtyas, "Penghimpunan Zakat Turun, LAZ Perlu Kolaborasi", 18 November 2018, https://www.republika.id/posts/6847/penghimpunan -zakat-turun-laz-perlu-kolaborasi. $\quad$ (diakses 18 November 2020).

13 Filantropi Indonesia, "Dompet Dhuafa", 22 September

2020,https://filantropi.or.id/anggota/dompetdhuafa\#: :text=Dompet\%20Dhuafa\%20adalah\%20Le mbaga\%20Filantropi,(prophetic\%20socio\%2Dtechnop reneurship). (diakses 22 September 2020).

${ }^{14}$ Yaya Sanjaya, Analisa Fungsi Anggaran Sebagai Alat Perencanaan dan Pengendalian terhadap Kinerja Keuangan Pengelolaan Dana (Studi pada Pengelolaan Dana di Dompet Dhuafa Jawa Barat) (TesisUniversitas Pendidikan Indonesia, Bandung, 2013), 5. 
terdampak Covid-19 sehingga muzaki mengetahui alokasi dananya, salah satunya adalah diperuntukkan untuk bantuan sosial dampak pandemi sampai informasi keislaman yang bisa menambah pengetahuan akan Islam. Selain itu, salah satu hal yang menjadikan Dompet Dhuafa mengalami peningkatan penghimpunan zakat adalah karena adanya layanan digital dan website dompetdhuafa merupakan salah satu layanan zakat online yang dikelola oleh lembaga Dompet Dhuafa. ${ }^{15}$

Meski di tengah pandemi Covid-19 yang menjadikan kondisi daya ekonomi masyarakat menurun, namun Dompet Dhuafa bisa mengalami peningkatan dalam menghimpun dana dan melampaui target dari tahun sebelumnya pada periode Ramadan 1441 Hijriah. Dana yang terhimpun sebesar $105 \mathrm{M}$ dengan pertumbuhan 16,32 persen dibandingkan tahun 2019. Hal tersebut bisa meningkat, karena salah satu strategi yang digunakan pada saat ramadan adalah dengan meningkatkan volume transaksi berbasis digital dengan harapan bisa memudahkan muzaki dalam berzakat karena hanya menggunakan ponsel. ${ }^{16}$ Selain itu, Direktur Eksekutif Dompet Dhuafa, Imam Rulyawan mengatakan bahwa penghimpunan dana selama bulan ramadan

\footnotetext{
${ }^{15}$ Hendy Dinata, “Dompet Dhuafa Raih Pertumbuhan ZIS 16,32 Persen saat Ramadhan $1441 \mathrm{H}^{\prime \prime}, 15$ September 2020,https://m.ayojakarta.com/read/2020/05/2 4/18276/dompet-dhuafa-raih-pertumbuhan-zis1632-persen-saat-ramadan-1441-h. (diakses 15 September 2020).

16 Hendy Dinata, “Dompet Dhuafa Raih Pertumbuhan ZIS 16,32 Persen saat Ramadhan $1441 \mathrm{H}^{\prime \prime}, 15$ September 2020, https://m.ayojakarta.com/read/2020/05/24/182 76/dompet-dhuafa-raih-pertumbuhan-zis-1632persen-saat-ramadan-1441-h. (diakses 15 September 2020).
}

2020 mengalami kenaikan yang signifikan dari sisi digital, peningkatan tersebut mencapai 85 persen dibandingkan ramadan tahun lalu. ${ }^{17}$

Terus tumbuhnya penghimpunan zakat Dompet Dhuafa, menjadikan Dompet Dhuafa mendapatkan penghargaan dalam kategori Program Fundraising Zakat terbaik pada Kamis, 7 September 2020 yang dilakukan secara daring melalui aplikasi zoom. Penghargaan tersebut didapat dari adanya penyelenggaraan Indonesian Fundraising Awards 2020 yang diselenggarakan oleh Institut Fundraising Indonesia. ${ }^{18}$

Dari uraian di atas, dapat mengindikasikan bahwa layanan Dompet Dhuafa makin dipilih dan diakui masyarakat untuk menyalurkan zakatnya di masa pandemi. bukan hanya karena promosinya yang gencar dilakukan, namun juga pemenuhan produk dan layanan yang dapat dirasakan manfaatnya oleh masyarakat. Hal tersebut sangat didukung oleh website yang telah dimiliki Dompet Dhuafa sebelum pandemi sehingga dapat melayani kebutuhan berzakat masyarakat luas tanpa perlu tatap muka.

\footnotetext{
${ }^{17}$ Hiru Muhammad, "Penghimpunan Dana Digital DD Pada Ramadhan Naik 85 Persen”, 16 September 2020, https://republika.co.id/berita/qcbh76380/pengh impunan-dana-digital-dd-pada-ramadhan-naik85-persen. (diakses 16 September 2020). ${ }^{18}$ Republika, "Lewati 27 Tahun, Dompet Dhuafa Kembali Sabet Penghargaan", 15 September 2020, https://republika.co.id/berita/qd8ga5349/lewati 27-tahun-dompet-dhuafa-kembali-sabetpenghargaan. (diakses 15 September 2020).
} 
Dari latar belakang tersebut, layanan zakat online Dompet Dhuafa menarik untuk dikaji dari sudut pandang teori pemasaran jasa. Khususnya pada aspek produk jasa berupa layanan inti dan layanan tambahan yang dimiliki. Dengan demikian, studi ini bertujuan untuk mengupas bagaimana layanan zakat online pada lembaga Dompet Dhuafa baik produk inti maupun layanan tambahan yang spesifik pada website dompetdhuafa.org yang masih relevan digunakan di masa pandemi Covid-19. Di mana layanan online tersebut merupakan layanan yang dikelola langsung oleh pihak Dompet Dhuafa, dengan begitu bisa mengetahui bentuk layanan yang disediakan oleh Dompet Dhuafa untuk memudahkan muzaki dalam menyalurkan zakatnya.

Adanya studi ini harapannya bisa menjadi tambahan referensi bagi lembaga dakwah, lembaga sosial, atau lembaga amil zakat dalam merumuskan produk jasa, khususnya dalam merumuskan layanan zakat online yang tetap mengedepankan protokol kesehatan di masa pandemi Covid-19 terkait seperti apa layanan-layanan zakat online yang disediakan Dompet Dhuafa dan masih relevan digunakan meski dibuat sebelum pandemi sehingga bisa memudahkan dalam pengumpulan zakat. Apalagi pandemi membawa dampak terhadap perekonomian masyarakat, sehingga dengan adanya zakat bisa menjadi solusi masalah tersebut. ${ }^{19}$ Selain itu peningkatan zakat ini bisa meminimalisir potensi kesenjangan sosial antara si kaya dan si miskin. ${ }^{20}$

\footnotetext{
${ }^{19}$ Koran Sindo, "Zakat Solusi di Tengah Pandemi", diakses 15 November 2020, https://nasional.sindonews.com/read/16041/15 Lzakat-solusi-di-tengah-pandemi-corona1588547145

${ }^{20}$ Mustafa Kamal M. Jamil, "Kedudukan Zakat Dalam Sistem Ekonomi Islam", diakses 22 September 2020,
}

Studi terdahulu yang meneliti tema sejenis adalah yang pertama, artikel yang ditulis oleh Santika Pertiwi dengan judul Produk Jasa Lembaga Daarul Quran Travel Haji dan Umrah Perspektif Pemasaran Jasa. Tujuan dari studi tersebut adalah untuk memaparkan porduk jasa lembaga Daarul Quran Travel Haji dan Umrah dengan pendekatan teori pemasaran jasa. Karena objek yang dikaji memiliki perbedaan, tentunya menghasilkan temuan yang berbeda meski dengan pendekatan yang sama. Studi tersebut menunjukkan deskripsi produk inti Daqu Travel serta delapan layanan tambahan yang dimilikinya. Serta pada studi tersebut bukan meneliti lembaga zakat sehingga terdapat perbedaan produk yang dikaji. ${ }^{21}$

Kedua, artikel yang ditulis oleh Abdul Rahman Sakka dan Latifatul Qulub dengan judul Efektivitas Penerapan Zakat Online Terhadap Peningkatan Pembayaran Zakat pada Lembaga Dompet Dhuafa Sulsel. Pendekatan yang digunakan adalah teori zakat online dan teknologi finansial dalam studi tersebut. Karena pendekatan yang digunakan berbeda maka tentunya akan menghasilan temuan yang berbeda meski objeknya sama. Studi tersebut menunjukkan adanya peningkatan yang signifikan pada penerimaan zakat secara online dan realisasinya lebih tinggi dari target yang dicanangkan sehingga layanan zakat online optimal untuk mengumpulkan zakat. ${ }^{22}$

http://www.ekonomiislam.net/2017/09/kedudu kan-zakat-dalam-sistem-ekonomi-islam.html

${ }^{21}$ Santika Pertiwi, "Produk Jasa Lembaga Daarul Quran Travel Haji dan Umrah Perspektif Pemasaran Jasa", Jurnal Pengembangan IImu Dakwah 02, no.01 (2020): 179.

${ }^{22}$ Abdul Rahman Sakka dan Latifatul Qulub, "Efektivitas Penerapan Zakat Online terhadap 
Ketiga,artikel yang ditulis oleh Andrika Saputra, Alvi Furwanti Alwie, dan Any Widayatsari dengan judul Pengaruh Promosi dan Kualitas Pelayanan Terhadap Kepercayaan dan Loyalitas Donatur Dompet Dhuafa Riau. Meski objek yang dikaji memiliki kesamaan namun pedekatan yang digunakan memiliki perbedaan tentunya akan menghasilkan temuan yang berbeda. Studi tersebut menunjukkan bagaimana pengaruh masing-masing promosi dan kualitas pelayanan terhadap kepercayaan dan loyalitas donatur dengan pendekatan survei terhadap 312 donatur Dompet Dhuafa Riau. $^{23}$

Dari keseluruhan studi terdahulu, belum ada yang membahas mengenai layanan zakat online apa saja yang diberikan oleh Dompet Dhuafa kepada muzaki dalam perspektif teori Pemasaran Jasa Christopher Lovelock. Pada kajian terdahulu terkait Dompet Dhuafa kebanyakan meneliti efektivitas layanan zakat online dan promosi. Serta sejauh ini yang membahas terkait layanan produk jasa masih pada lembaga yang berbeda karena buka pada lembaga zakat. Dimana studi ini akan membedah produk inti dan layanan tambahan pada layanan zakat online Dompet Dhuafa khususnya pada website dompetdhuafa.org yang makin dibutuhkan di masa pandemi Covid-19 karena tidak perlu bertemu langsung dengan pihak lembaga.

Peningkatan Pembayaran Zakat pada Lembaga Dompet Dhuafa Sulses", Jurnal Ekonomi Islam 01, no.02 (2019): 69.

${ }^{23}$ Andrika Saputra, Alvi Furwanti Alwie, dan Any Widayatsari, "Pengaruh Promosi dan Kualitas Pelayanan Terhadap Kepercayaan dan loyalitas Donatur Dompet Dhuafa Riau", Jurnal Dakwah Risalah 31, no.01 (2020): 70.
Studi ini menggunakan metode penelitian kualitatif, ${ }^{24}$ dengan sumber data primer yang meliputi deskripsi produk yang ada di website resmi dompetdhuafa.org, serta media sosial lain untuk mendukung data pada website seperti YouTube Dompet Dhuafa TV, instagram dompet_dhuafa, twitter@Dompet_Dhuafa, serta ungkapan dari pihak Dompet Dhuafa. Sedangkan sumber data sekunder meliputi jurnal dari Gustia Djuanda tentang Pelaporan Zaat Pengurangan Pajak Peghasilan, jurnal dari Adzana Abdul Zabar dan Fahmi Novianti tentang Keamanan http dan https Berbais Web, informasi online dari Qwords tentang Chrome Security Warning dari pihak lain yang membahas mengenai layanan online Dompet Dhuafa dalam rentang waktu tahun 2020.

Teknik pengumpulan data yang digunakan dalam studi ini adalah menggunakan teknik dokumentasi. Sedangkan untuk menganalisis datanya adalah dengan mengikuti model analisis Miles dan Huberman yang terdiri dari 3 aktivitas yaitu mereduksi data, ${ }^{25}$ menyajikan data, ${ }^{26}$ dan menarik kesimpulan. ${ }^{27}$ Kemudian untuk menguji keabsahan datanya adalah dengan melakukan triangulasi data. ${ }^{28}$

\section{Produk Jasa}

Dalam rangka memenuhi kebutuhan serta keinginan, tiap manusia akan memenuhinya dengan produk barang atau jasa. Karena

\footnotetext{
${ }^{24}$ Sugiyono, Metode Penelitian Kuantitatif, Kualitatif, dan $R \& D$ (Bandung: CV Alvabeta, 2017), 9.

${ }^{25}$ Wahyu Purhantara, Metode Penelitian untuk Bisnis (Yogyakarta: Graha Ilmu, 2010), 247.

26 Ibid., 249.

27 Ibdi., 253.

28 Ibid., nomer 26, 27.
} 
produk sendiri adalah segala sesuatu yang ditawarkan ke pasar memenuhi kebutuhan dan keinginan pasar termasuk barang fisik, jasa, pengalaman, acara, orang, tempat, properti, organisasi, informasi, dan ide. ${ }^{29}$ Produk memiliki 5 tingkatan produk yang membentuk hirarki nilai pelanggan, yakni (1) core benefit, yaitu layanan atau manfaat inti yang sesungguhnya dibeli pelanggan; (2) basic product, yaitu bentuk dasar dari satu produk; (3) expected product, yaitu mempersiapkan produk yang diinginkan oleh pembeli; (4) augmented product, yaitu sesuatu yang membedakan antara produk yang ditawarkan dengan produk yang ditawarkan pesaing; (5) potential product, yaitu semua argumentasi dan perubahan bentuk yang dialami produk dimasa yang akan datang. ${ }^{30}$

Namun, produk jasa memiliki perbedaan dengan produk barang, karena produk jasa biasanya tidak bisa dimiliki oleh pasar, seperti yang disampaikan oleh Lovelock bahwa jasa adalah kegiatan yang ditawarkan oleh penyedia jasa kepada pasar dalam jangka waktu tertentu dan bisa memberikan manfaat serta nilai positif untuk pasar, namun biasanya pasar tidak memiliki hak miliki dari fasilitas fisik atas pelayanan jasa yang diberikan oleh penyedia jasa. ${ }^{31}$

Menurut Lovelock, Jochen Wirtz, dan Jacky Mussry, pemasaran jasa terdiri dari produk inti yang menjawab kebutuhan utama pasar dan layanan tambahan berupa berbagai aktivitas lain diluar produk inti yang

${ }^{29}$ Kotler dan Keller, Manajemen Pemasaran, Jilid

1, Edisi ke 13 (Jakarta: Erlangga, 2009), 4.

${ }^{30}$ Muhammad Sutio, "Pengaruh Tingkatan Produk Terhadap Loyalitas Pelanggan”, Jurnal

Digest Marketing vol.03, no. 1 (2018): 54.

${ }^{31}$ Lovelock, Pemasaran Jasa Manusia,

Teknologi, Strategi, Jilid 1, Edisi ketujuh, 16.

32 Ibid., 98. memberikan tambahan pada produk inti, mempermudah penggunaannya dan memperkuat nilainya bagi keseluruhan pengalaman pelanggan. ${ }^{32}$

Produk memiliki unsur atau komponen utama yang diberikan kepada pasar untuk menyelesaikan masalah pasar serta memberikan nilai manfaat. Sehingga produk inti menjadi hal yang mendasari produk jasa karena produk inti memberikan solusi terhadap masalah utama yang dialami oleh pasar. $^{33}$ Kemudian Lovelock juga menjelaskan bahwa, the core product is "what" the customer is fundamentally buying. ${ }^{34} \mathrm{Hal}$ tersebut menunjukkan bahwa produk inti adalah apa yang sesungguhnya dibeli oleh pelanggan.

Kemudian Lovelock dan Wright membagi layanan tambahan kedalam 2 besaran layanan tambahan yaitu layanan yang mempermudah dan layanan yang memperkuat serta terdapat sub-subnya dari kedua besaran layanan tersebut. ${ }^{35}$ Detail pembagiannya adalah sebagai berikut : layanan yang mempermudah terdiri dari (1) Informasi, yaitu kumpulan jasa pelengkap yang memudahkan pembelian dan penggunaan jasa dengan menunjukkan fitur dan kinerja produk inti sebelum penggunaan, selama, dan setelah penyerahan jasa; ${ }^{36}(2)$ penerimaan pesanan, yaitu kumpulan jasa pelengkap yang memudahkan kegiatan pembelian dengan menciptakan prosedur yang cepat, akurat,

\footnotetext{
33 Ibid.,

${ }^{34}$ Jochen Wirtz dan Christopher Lovelock, Service Marketing: People, Technology, Strategy (USA : Pearson Education, 2016), 125.

${ }^{35}$ Christoper H. Lovelock dan Lauren K. Wright, Manajemen Pemasaran Jasa (Jakarta: PT Macanan Jaya Cemerlang, 2005), 190. ${ }^{36}$ Ibid., 191.
} 
dan tanggap untuk menerima permohonan keanggotaan, melakukan pemesanan, atau melakukan reservasi; ${ }^{37}(3)$ penagihan, yaitu sekumpulan jasa pelengkap yang memudahkan pelanggan melakukan pembelian terhadap produk jasa dengan menyediakan dokumentasi yang jelas, tepat waktu, akurat, dan relevan tentang apa yang harus dibayar dan informasi mengenai bagaimana cara pelanggan membayarnya; ${ }^{38}$ (4) pembayaran, yaitu kumpulan jasa pelengkap yang memudahkan pembelian dengan menawarkan pilihan metode dalam pembayaran sehingga bisa dilakukan dengan efisien. ${ }^{39}$

Layanan yang memperkuat terdiri dari (1) konsultasi, yaitu kumpulan jasa pelengkap yang bisa memberikan jawaban kepada pelanggan yang membutuhkan saran, konseling, atau pelatihan sehingga bisa mendapatkan manfaat yang besar dari penggunaan produk jasa; ${ }^{40}$ (2) keramahan, yaitu kumpulan jasa pelengkap yang menambah nilai dengan cara menjadikan pelanggan layaknya tamu yang harus dilayani dan disediakan segala kebutuhan perlengkapan kenyamanannya sehingga mampu mengantisipasi kebutuhan pelanggan selama bertinteraksi dengan penyedia jasa; ${ }^{41}$ (3) pengamanan, yaitu kumpulan jasa pelengkap yang mampu menambah nilai dengan membantu pelanggan memberikan pengamanan

37 Ibid., 193.

38 Ibid., 194.

39 Ibid., 196.

40 Ibid., 197.

41 lbid., 199.

42 Ibid., 201.

43 Ibid., 203.

44 Dompet Dhuafa, "Yayasan Dompet Dhuafa Republika",14 September 2020,http://www.dompetdhuafa.org/id/tentangkami /detail/profil.(diakses 14 September 2020). terhadap barang milik pribadi pelanggan ke tempat pelanggan membeli produk jasa (produk inti); $;^{42}$ (4) pengecualian, yaitu kumpulan jasa pelengkap yang memberikan tambahan nilai dengan menanggapi permintaan khusus, memecahkan masalah, menangani pengaduan, saran, dan pujian, dan menyediakan kompensasi jika ada kegagalan jasa. ${ }^{43}$

\section{Profil Dompet Dhuafa}

Yayasan Dompet Dhuafa Republika merupakan filantropi Islam yang berkhidmat dalam rangka pemberdayaan kaum duafa dengan pendekatan budaya dan wirausaha sosial. ${ }^{44}$ Dengan salah satu sumber dananya adalah dari zakat. ${ }^{45}$ Latar belakang berdirinya Dompet Dhuafa adalah dari adanya peristiwa pada bulan April tahun 1993, di mana pada saat itu Harian Umum Republika yang baru berusia 3 bulan menyelenggarakan promosi di stadion Kridosono, Yogyakarta kemudian mengetahui bahwa pengurus Crop Dakwah Pedesaan hanya mendapat honor sebesar Rp 6.000. Hal tersebut yang menginspirasi lahirnya Dompet Dhuafa dan pada tanggal 2 Juli 1993, sebuah rubrik di halaman muka Harian Umum Republika dengan tajuk "Dompet Dhuafa" dibuka. Tanggal tersebut yang kemudian ditandai sebagai hari jadi Dompet Dhuafa Republika. ${ }^{46}$

45 Filantropi Indonesia, "Dompet Dhuafa", 13 September 2020,

https://filantropi.or.id/anggota/dompetdhuafa\#: :text=Dompet\%20Dhuafa\%20adalah\%20Le mbaga\%20Filantropi,(prophetic\%20socio\%2Dtechnop reneurship). (diakses 13 September 2020).

46 Dompet Dhuafa, "Yayasan Dompet Dhuafa Republika", $15 \quad$ September 2020,http://www.dompetdhuafa.org/id/tentangkami Ldetail/profil. (diakses 15 September 2020). 
Dompet Dhuafa memiliki visi berupa terwujudnya masyarakat dunia yang berdaya melalui pelayanan, pembelaan, dan pemberdayaan berbasis pada sistem berkeadilan. Dengan misinya adalah sebagai berikut, yang pertama adalah membangun gerakan pemberdayaan dunia untuk mendorong transformasi tatanan sosial masyarakat berbasis nilai keadilan. Kedua, mewujudkan pelayanan, pembelaan, dan pemberdayaan yang berkesinambungan serta berdampak pada kemandirian masyarakat yang berkelanjutan. Ketiga, mewujudkan keberlanjutan organisasi melalui tata kelola yang baik, profesional, adaptif, kredibel, akuntabel, dan inovatif. ${ }^{47}$

Salah satu layanan zakat online yang dimiliki oleh Dompet Dhuafa adalah website dompetdhuafa.org yang memberikan berbagai pengetahuan yang berhubungan dengan lembaga Dompet Dhuafa. Salah satunya adalah adanya penjelasan mengenai aktivitas ikhtiar Dompet Dhuafa untuk terus menebar kebaikan kepada keseluruhan penjuru dunia yang dirangkum dalam berita.

Dalam berita tersebut, muzaki bisa mengetahui kegiatan-kegiatan yang dilakukan oleh Dompet Dhuafa dalam hal sosial kemanusiaan seperti membantu korban banjir, evakuasi korban tenggelam di sungai, dan sampai pada kegiatan sosial membantu masyarakat yang terdampak Covid19.

47 Dompet Dhuafa, "Visi \& Misi", diakses 15 September 2020,

http://dompetdhuafa.org/id/tentangkami/detail/visi-misi

${ }^{48}$ Dompet Dhuafa, "Deskripsi Laman Depan”, 14 September 2020,

http://www.dompetdhuafa.org/. (diakses 14

September 2020).

${ }^{49}$ Dompet Dhuafa, "Bayar Zakat Online di

Dompet Dhuafa”,23 September
Selain itu, secara umum website dompetdhuafa.org ini menjelaskan mengenai program-program Dompet Dhuafa, layanan donasi, kemitraan, berita, cara bergabung dengan Dompet Dhuafa, dan tentang Dompet Dhuafa (profil, visi misi, stuktur organisasi, cabang, dan lan-lain) ${ }^{48}$ Dengan begitu, adanya website dompetdhuafa.org ini akan menjadikan berbagai pihak bisa mengetahui seperti apa lembaga Dompet Dhuafa mulai kegiatankegiatan yang dilakukan, program-program yang diadakan, cara berdonasi, dan lain sebagainya. Salah satu tujuan lembaga Dompet Dhuafa membuat website dompetdhuafa.org adalah sebagai layanan zakat online bagi muzaki yang ingin membayar zakat secara online. ${ }^{49}$

\section{Produk Inti Layanan Zakat Online pada Website dompetdhuafa.org} Pada akhir tahun 2019 dunia dihadapkan dengan adanya virus Covid-19 yang berasal dari Kota Wuhan, Cina. Hal tersebut menimbulkan kekhawatiran dan ketakutan di kalangan masyarakat luas. Kemudian pemerintah berusaha membuat kebijakan dalam rangka memutus rantai penularan virus Covid-19 yaitu menjaga jarak, sering mencuci tangan atau menggunakan antiseptik, bahkan membuat aturan kerja dari rumah. ${ }^{50}$

2020,https://www.dompetdhuafa.org/id/berita/ detail/tips-bayar-zakat-online. (diakses 23

September 2020).

50 Eka Suci Fitriani, Raden Agrosamhyo, dan Ely Mansur, "Strategi Penghimpunan dan Penyaluran Zakat, Infak, Sedekah (ZIS) Dalam Program Sebar Sembako Pada Masa Pandemi Covid-19 di Badan Amil Zakat Nasional (BAZNAS) Provinsi Bali", Jurnal Ilmu Pnedidikan dan Ekonomi Vol.5, no.9 (2020): 2. 
Dari kondisi tersebut, muzaki juga harus mulai adaptasi dalam berbagai hal, salah satunya adalah berzakat. Karena zakat adalah sebuah kewajiban seorang muslim yang artinya harus dikeluarkan bagi yang mampu, ${ }^{51}$ maka harus tetap dikeluarkan meski dalam masa pandemi Covid-19. Maka pembayaran secara online adalah media paling solutif diterapkan di masa pandemi karena muzaki tetap bisa menyalurkan zakat dengan aman dan tepat sasaran. ${ }^{52}$

Dompet Dhuafa memiliki salah satu layanan zakat online yaitu website dompetdhuafa.org, dimana website ini adalah layanan yang memudahkan muzaki dalam hal membayar zakat secara praktis dan tidak perlu berinteraksi langsung dengan petugas Dompet Dhuafa dan makin relevan digunakan di masa pandemi Covid-19 meski website ini ada sebelum pandemi. Kemudian nantinya dana zakat yang disalurkan oleh muzaki kepada lembaga, akan digunakan untuk berbagai program yang dapat membantu mustahik. ${ }^{53}$

Selain itu, dalam website dompetdhufa.org terdapat laporan keungan dan laporan tahuhan yang bisa diakses oleh muzaki sehingga muzaki bisa mengetahui alokasi dana yang disalurkan oleh muzaki tanpa takut dananya tidak disalurkan kepada yang tidak berhak. Jika muzaki ingin mengetahui

\footnotetext{
${ }^{51}$ Gustian Djuanda, Pelaporan Zakat Pengurang Pajak Penghasilan (Jakarta: PT Raja Grafindo Persada, 2006), 1.

52 Forum Zakat, "Strategi Zakat Online di Tengah Pandemi", $15 \quad$ November 2020,https://forumzakat.org/strategi-zakat-online-ditengah-pandemi-harzolnas/. ( diakses 15 November 2020).

${ }^{53}$ Dompet Dhuafa, “Mudahnya Bayar Zakat profesi di Dompet Dhuafa Hanya Dengan 3 Langkah!",18 Oktober 2020,
}

laporan tahunan dan laporan keuangan maka bisa mengunduhnya. ${ }^{54}$ Selain itu, muzaki juga bisa mengetahui kegiatankegiatan sosial yang dilakukan oleh lembaga Dompet Dhuafa pada bagian Berita di lama depan website dompetdhuafa.org. ${ }^{55}$

Dengan adanya laporan keuangan, laporan tahunan, maupun kegiatan sosial yang dilakukan oleh lembaga bisa menjadi jaminan bagi muzaki bahwa zakat yang disalurkan akan dikelola dan dialokasikan kepada mustahik yang berhak. Dengan begitu muzaki bisa yakin bahwa Dompet Dhuafa adalah lembaga yang tepat untuk menyalurkan zakat.

Dari data-data tersebut, menunjukkan bahwa muzaki memiliki kendala untuk menyalurkan zakat secara langsung (bertemu dengan pihak lembaga penghimpun zakat atau dana umat lainnya) di masa pandemi Covid-19 karena rawan terpapar virus Covid-19. Kemudian Dompet Dhuafa yang telah memiliki layanan zakat online dari sebelum pandemi dan masih relevan digunakan di masa pandemikarena bisa memudahkan muzaki untuk menyalurkan zakat tanpa harus berinteraksi langsung dengan pihak lembaga kemudian zakat yang diberikan nantinya akan digunakan untuk membantu mustahik.

https://dompetdhuafa.org/id/berita/detail/baya r-zakat-profesi. ( diakses 18 Oktober 2020). ${ }^{54}$ Dompet Dhuafa, "Mudahnya Bayar Zakat profesi di Dompet Dhuafa Hanya Dengan 3 Langkah!", 31 Desember 2020, https://dompetdhuafa.org/id/berita/detail/baya r-zakat-profesi. (diakses 31 Desember 2020).

${ }^{55}$ Dompet Dhuafa, "Deskripsi Laman Depan", 31 Desember 2020, http://www.dompetdhuafa.org/. (diakses 31 Desember 2020). 
Kemudian, dengan muzaki membayar zakat melalui layanan zakat online dompet dhuafa maka menunjukkan bahwa muzaki telah memakai jasa layanan zakat online Dompet Dhuafa yang ditawarkan kepada muzaki. Sedangkan muzaki memiliki kewajiban untuk menunaikan zakat. ${ }^{56}$ Sehingga, ketika muzaki berzakat di lembaga tersebut menunjukkan bahwa muzaki mengeluarkan kewajibannya dan mempercayakan kepada lembaga supaya dikelola dan diberikan kepada yang berhak.

Sehingga, produk inti untuk menjawab masalah muzaki yang ingin menyalurkan zakat namun mengalami kesulitan untuk menjangkau lokasi, kesulitan waktu untuk datang ke kantor lembaga, serta adanya konteks saat ini yang harus menerapkan protokol kesehatan di masa pandemi adalah memberikan kemudahan bagi muzaki yang ingin menyalurkan zakat tanpa harus bertemu langsung dengan pihak lembaga apalagi di masa pandemi Covid-19 sehingga muzaki tetap aman dari virus Covid-19 dan bisa merasa tepat sasaran ketika menyalurkan zakat di lembaga Dompet Dhuafa karena ditunjukkan laporan keuangan, laporan tahunan, serta kegiatan sosial yang dilakukan Dompet Dhuafa. Hal tersebut sesuai dengan produk jasa yang disampaikan Christopher Lovelock, bahwa produk inti merujuk pada nilai dari pemecahan masalah, ${ }^{57}$ serta apa yang sesungguhnya dibeli pelanggan. ${ }^{58}$

Adanya produk inti tersebut bisa memberikan kemudahan bagi muzaki yang ingin menyalurkan zakat tanpa perlu bertemu dengan pihak lembaga dan meski menyalurkan secara online namun tetap bisa memberikan secara tepat sasaran kepada yang membutuhkan karena zakat yang diberikan oleh muzaki akan dikelola dan disalurkan kepada mustahik. Sehingga muzaki tidak perlu khawatir, karena hanya dengan menggunakan ponsel maka muzaki sudah bisa menyalurkan zakat degan tepat sasaran kepada yang berhak.

\section{LayananInformasi}

Tampilan layanan informasi dapat dilihat pada gambar $1 .{ }^{59}$

\footnotetext{
${ }^{56}$ Gustian Djuanda, Pelaporan Zakat Pengurang Pajak Penghasilan (Jakarta: PT Raja Grafindo Persada, 2006), 1.

${ }^{57}$ Lovelock, Pemasaran Jasa Manusia, Teknologi, Strategi, Jilid 1, Edisi ketujuh, 98.
}

\footnotetext{
${ }^{58}$ Christopher Lovelock, Service Marketing: People, Technology, Strategy, 125.

59 Dompet Dhuafa, "Donasi",15 September 2020, https://donasi.dompetdhuafa.org/. (diakses 15 September 2020).
} 


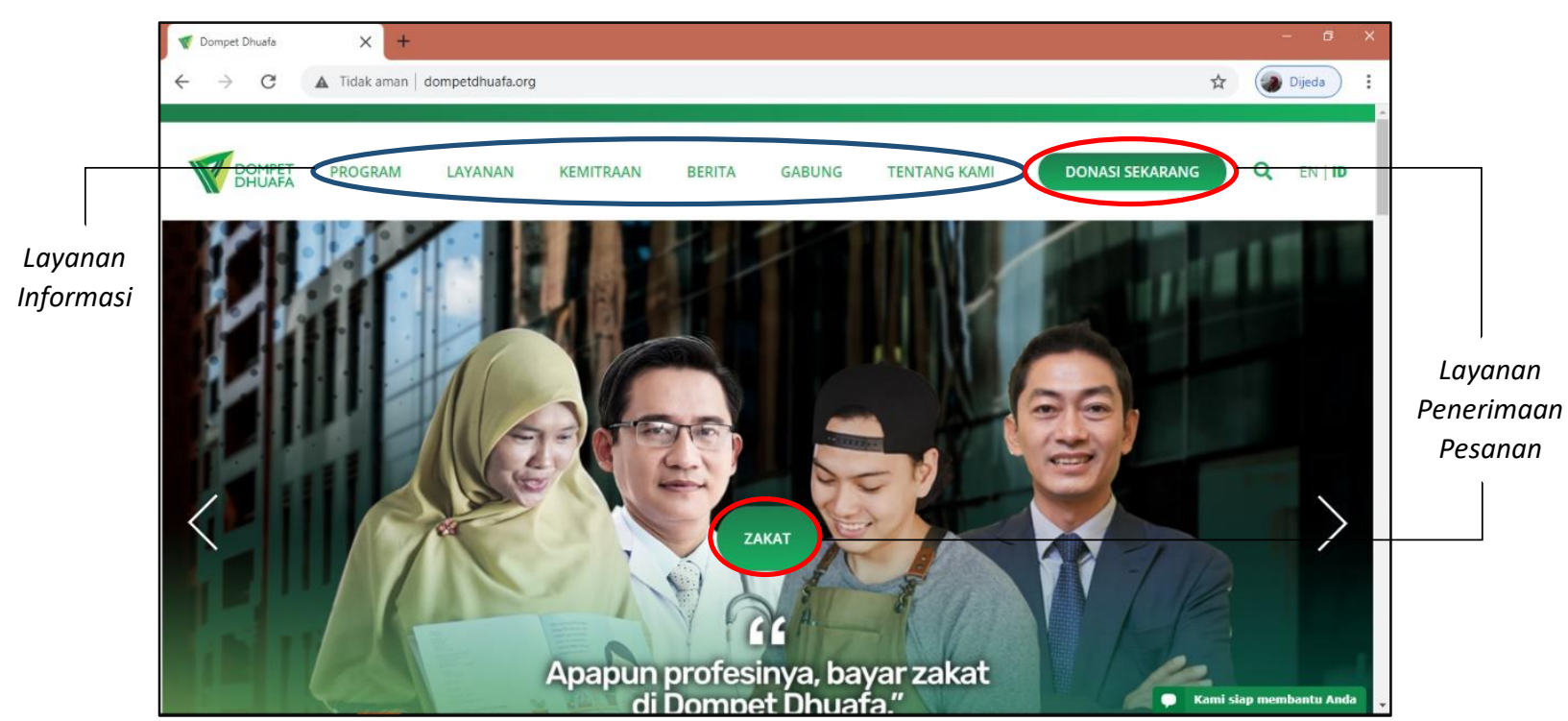

Gambar 1 - Layanan Informasi dan Penerimaan Pesanan dalam Website Dompet Dhuafa

Berpijak pada teori the flower of service dari Christopher Lovelock, bahwa layanan informasi yaitu kumpulan jasa pelengkap yang memudahkan pembelian dan penggunaan jasa dengan menunjukkan fitur dan kinerja produk inti sebelum penggunaan, selama, dan setelah penyerahan jasa, ${ }^{60}$ maka layanan informasi pada konteks website ini adalah penjelasan mengenai zakat, besarnya zakat yang perlu dibayar yang tertera pada website dompetdhuafa.org, serta setelah muzaki menyalurkan zakat.

Dompet Dhuafa memberikan berbagai informasi melalui website dompetdhuafa.org yang menunjang kemudahan muzaki dalam menyalurkan zakat secara aman dan tepat. Pertama adalah informasi mengenai kelembagaan mulai dari program, layanan, kemitraan, berita, gabungan, tentang Dompet Dhuafa. Dari pilihan-piihan tersebut, ketika diklik

${ }^{60}$ Lovelock, Pemasaran Jasa., 191. akan terhubung dengan penjelasanpenjelasan terkait dengan apa yang diklik. Kemudian, masih di laman depan pada bagian paling bawah terdapat informasi mengenai alamat Dompet Dhuafa Republika, nomor telepon, alamat email, profil, cara bergabung, program, social enterprise, konfirmasi donasi, donasi, serta media sosial yang dimiliki oleh Dompet Dhuafa. ${ }^{61}$ Informasi tersebut adalah informasi yang bisa didapatkan muzaki sebelum menyalurkan zakat karena dengan adanya informasi tersebut bisa menjadi pertimbangan muzaki apakah lembaga tersebut adalah lembaga yang tepat untuk menyalurkan zakat dan memberikan kemudahan untuk menentukan tempat penyaluran zakat yang tepat.

Kedua, informasi mengenai programprogram Dompet Dhuafa yang bisa meyakinkan muzaki untuk menyalurkan zakat pada lembaga karena muzaki bisa

61 Dompet Dhuafa, "Deskripsi Laman Depan”, 14 September 2020, http://www.dompetdhuafa.org/. (diakses 14 September 2020). 
mengetahui penyaluran zakat yang nantinya diberikan, yaitu terkait 5 pilar program utama mulai dari pendidikan, kesehatan, ekonomi, sosial dan dakwah, serta budaya. ${ }^{62}$ Jika masing-masing program tersebut di klik maka akan terhubung ke penjelasan program, seperti contoh ketika mengklik program pendidikan akan munculprofil Dompet Dhuafa dalam hal pendidikan, kemudian ada beastudi indonesia, makmal pendidikan, sekolah literasi indonesia, school for Refugees, serta program-program pendidikan lainnya yang ketika di klik juga akan terhubung ke penjelasan dari masingmasing program pendidikan tersebut. ${ }^{63}$

Ketiga, informasi mengenai kalkulator zakat. Informasi ini penting bagi muzaki yang mengalami kebingungan terkait berapa nominal yang perlu dizakatkan sesuai dengan nisabnya karena bisa membantu muzaki sebelum muzaki menyalurkan zakat. Dimana ketika muzaki menyalurkan zakat secara konvensional bisa langsung bertanya kepada pihak lembaga terkait cara penghitungan zakat, pada layanan online ada media lain yang bisa membantu menghitung zakat berupa kalkulator zakat. Saat diklik akan muncul pilihan zakat apa yang ingin di hitung mulai dari zakat penghasilan atau zakat harta, kemudian ketika salah satu pilihan zakat tersebut dipilih akan muncul kolom-kolom yang perlu diisi, jika sudah terisi semua akan muncul berapa nominal yang perlu di zakatkan. ${ }^{64}$

Keempat, informasi mengenai berita Dompet Dhuafa. Dikelompokkan menjadi

\footnotetext{
62 Ibid.,

63 Dompet Dhuafa, "Pendidikan", 15 November 2020, https://dompetdhuafa.org/id/program/kategori/1. (diakses 15 November 2020).

64 Dompet Dhuafa, "Tunaikan Zakat", 14 September 2020 ,
}

berita pendayagunaan, penghimpunan, inspirasi, media, event, press release, nasional, luar negeri, dan khazanah Islam yang jika salah satunya di klik akan muncul banyak artikel terkait. Contohnya ketika mengklik pilihan khazanah Islam maka akan muncul artikel seperti sumber-sumber rezeki menurut Alquran, teladan Rasulullah saw: rela bagikan simpanannya, mengapa wakaf termasuk amal jariyah?, dan sebagainya. ${ }^{65}$ Informasi ini bermanfaat bagi muzaki karena selain muzaki mengetahui terkait update kegiatan sosial yang dilakukan oleh Dompet Dhuafa, muzaki juga bisa mengetahui beritaberita yang bermanfaat seperti pada khazanah Islam karena pada berita ini bukan dalam rangka memberitahukan kegiatan sosial namun lebih pada berbagi nilai-nilai Islam. Sehingga selain mendapatkan informasi tentang kegiatan sosial juga bisa mendapatkan berbagai pengetahuan Islam yang secara tidak langsung juga bisa memotivasi muzaki untuk menyegerakan zakatnya karena sebagian berita terkait khazanah Islam berisi mengenai masalah dan prospektus zakat.

Dengan adanya keseluruhan informasiinformasi tersebut akan memberikan kemudahan bagi muzaki yang ingin menyalurkan zakatnya pada lembaga Dompet Dhuafa karena dengan adanya berbagi informasi tersebut akan menjadikan muzaki mengetahui berbagai fitur dan kinerja produk inti (kemudahan menyalurkan zakat) baik sebelum, selama, maupun setelah penyaluran zakat. Apalagi pada layanan informasi ini bukan hanya

http://www.dompetdhuafa.org/id/layanan/Kalkulator Zakat. (diakses 14 September 2020).

65 Dompet Dhuafa, "Deskripsi Laman Depan", 14 September 2020, http://www.dompetdhuafa.org/. (diakses 14 September 2020). 
memberikan pengetahuan mengenai penyaluran zakat atau program-program zakat namun juga terdapat informasi keislaman yang bisa menambah pengetahuan muzaki.

\section{Layanan Penerimaan Pesanan}

Tampilan layanan penerimaan pesanan dapat dilihat pada gambar 1 di atas. Setelah muzaki mendapatkan informasi seputar zakat dan muzaki ingin membayar zakat maka bisa melakukan pemesanan zakat. Menurut teori the flower of service dari Christopher Lovelock, penerimaan pesanan merujuk pada layanan tambahan berupa penerimaan permohonan keanggotaan, melakukan pemesanan, maupun reservasi, ${ }^{66}$ maka disini berarti permohonan keanggotaan sebagai donatur, melakukan pemesanan untuk berzakat, atau reservasi dalam berzakat supaya bisa memudahkan muzaki dalam berzakat.

Pada website dompetdhufa.org, sebelum muzaki membayar zakat, bisa melakukan registrasi donatur dengan mengikuti langkah-langkan yang disediakan pada websitemulai dari mengisi user identifikasi, nomor registrasi, email, ulangi email, kemudian klik daftar. ${ }^{67}$ Kemudian ketika muzaki hendak menunaikan zakat, bisa melakukan pemesanan dengan mengklik opsi donasi pada laman utama. Kemudian akan muncul formulir yang perlu diisi ketika muzaki hendak berzakat. ${ }^{68}$

Hal tersebut memberikan kemudahan bagi muzaki yang ingin menunaikan zakat tanpa

${ }^{66}$ Lovelock, Pemasaran Jasa., 193.

${ }^{67}$ Dompet Dhuafa, "Donasi", 15 September 2020, https://donasi.dompetdhuafa.org/. (diakses 15 September 2020). harus datang ke kantor lembaga yang berpotensi terpapar virus Covid-19, karena ketika akan melakukan pemesanan berzakat, muzaki tinggal mengisi formulir yang muncul di layar telepon. Sehingga muzaki tidak akan merasa ribet atau merasa memerlukan banyak waktu jika ingin berdonasi karena sangat efisien dan membutuhkan sedikit waktu untuk mengisi formulir yang disediakan, apalagi selain menyalurkan zakat, muzaki juga bisa mendaftar menjadi donatur lembagayang bisa dilakukan secara onlinejuga. Selain mengklik pilihan donasi, muzaki yang ingin berzakat juga bisa mengklik pilihan zakat pada laman depan website dompetdhufa.org.

Sebenarnya sama saja dengan pilihan donasi karena nantinya mengisi formulir yang sama, namun yang membedakan adalah terdapat ungkapan-ungkapan dari mustahik dan para tokoh tentang penilaian positif lembaga Dompet Dhuafayang bisa menjadikan muzaki lebih yakin untuk menyalurkan zakat di lembaga tersebut. Seperti, ungkapan dari Amid yang merupakan petani sayur binaan Dompet Dhuafa, beliau mengatakan "beruntung hidup saya berubah 180 derajat dari pecandu narkoba menjadi berdaya dan bermanfaat. Semua ini karena Allah dan juga zakat dari para donatur Dompet Dhuafa." Selain itu juga ada ungkapan dari para tokoh yang percaya terhadap Dompet Dhuafa, seperti Ustaz Abdul Somed, Bambang Widjojanto (Mantan Komisioner KPK), dan Sofyan Djalil (Menteri Agraria dan Tata Ruang atau Kepala BPN RI). ${ }^{69}$

68 Ibid.,

$69 \mathrm{lbid}$. 


\section{Layanan Penagihan}

Tampilan layanan penagihan dapat dilihat pada gambar berikut: ${ }^{70}$

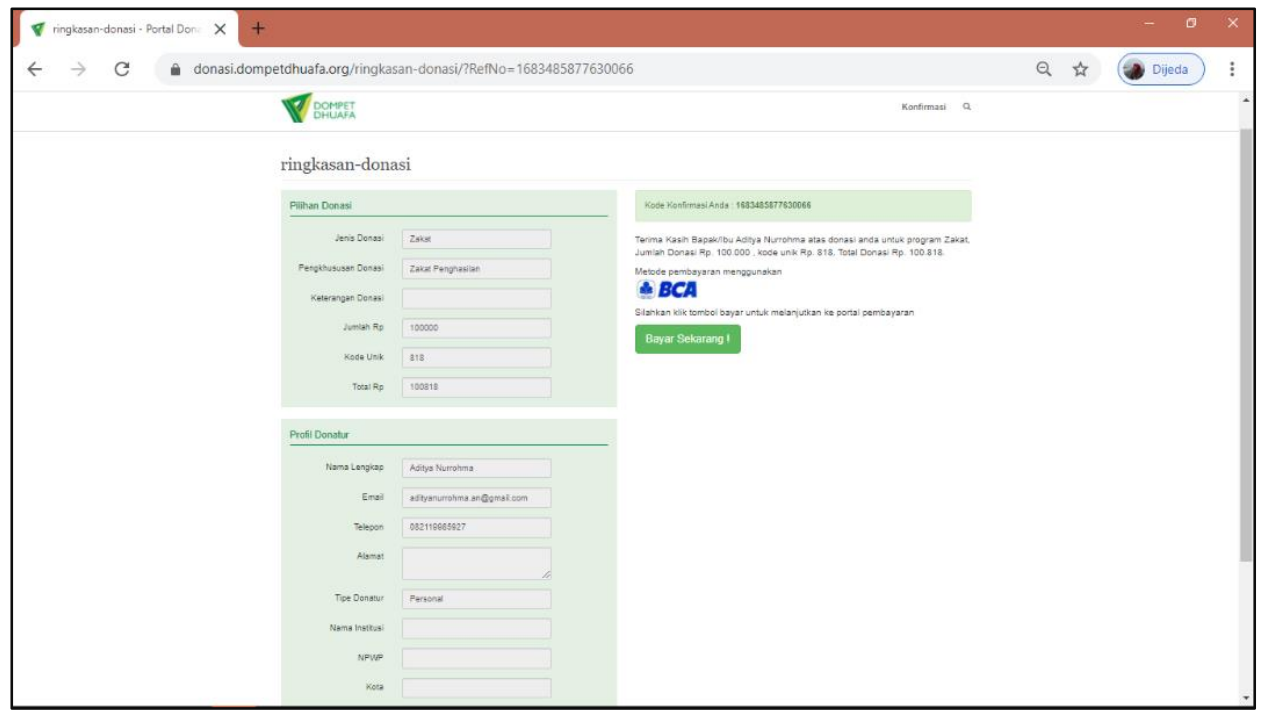

Gambar 2 - Layanan Penagihan pada Website Dompet Dhuafa

Setelah muzaki menyelesaikan pemesanan untuk membayar zakat maka akan ada penagihan mengenai berapa nominal yang perlu dizakatkan. Jika melihat teori the flower of service dari Christopher Lovelock, dimana penagihan merupakan layanan tambahan yang berisi dokumen penagihan yang perlu dibayar, ditambah dengan informasi tentang bagaimana membayarnya, ${ }^{71}$ sehingga dalam hal ini merujuk pada layanan tambahan yang berisi dokumen penagihan yang perlu dibayar oleh muzaki ketika akan membayar zakat serta tambahan informasi mengenai bagaimana cara muzaki bisa membayar zakatnya.

Layanan penagihan Dompet Dhuafa bisa diketahui ketika pada laman penerimaan

\footnotetext{
70 Dompet Dhuafa, "Ringkasan-Donasi", 16 September 2020, https://donasi.dompetdhuafa.org/ringkasandonasi/?RefNo=167806233935921. $\quad$ (diakses 16 September 2020).

71 Lovelock, Pemasaran Jasa., 194.
}

pesan muzaki memilih untuk berdonasi dengan metode tertentu baik transfer bank maupun payment online kemudian mengklik donasi maka muncul kolom-kolom data diri yang perlu diisi lagi namun ada beberapa yang sudah diisi sesuai data diri ketika membuat pesanan berzakat mulai dari jenis donasi, pengkhususan donasi, keterangan donasi, jumlah idr, biaya layanan idr, total idr, nama lengkap, email, nomor telepon, tipe donatur, dan negara. Sedangkan data yang belum terisi dan perlu diisi oleh muzaki adalah alamat, nama institusi, NPWP, Kota, Kodepos, dan provinsi. Tambahan data yang perlu diisi adalah supaya muzaki mendapakan manfaat sebagai pengurangan Penghasilan Kena Pajak (PKP). ${ }^{72}$

\footnotetext{
${ }^{72}$ Dompet Dhuafa, "Ringkasan-Donasi", 16 September 2020, https://donasi.dompetdhuafa.org/ringkasandonasi/?RefNo=167806233935921. (diakses 16 September 2020).
} 
Layanan penagihan ini bisa menjadi pengingat bagi muzaki untuk melanjutkan pembayaran zakat sesuai dengan nominal yang tertera pada penagihan, sehingga meski muzaki tidak diingatkan secara langsung oleh pihak lembaga (ketika berzakat secara konvensional atau datang langsung) namun pada website dompetdhuafa.org tetap ada penagihan yang mendukungproduk inti supaya muzaki menyalurkan zakat dengan mudah. Apalagi dalam layanan penagihan terdapat nominal yang akurat, tentunya bisa menambah kepercayaan muzaki untuk melanjutkan berzakat di lembaga Dompet Dhuafa.

\section{Layanan Pembayaran}

Tampilan layanan pembayaran dapat dilihat pada gambar berikut: ${ }^{73}$

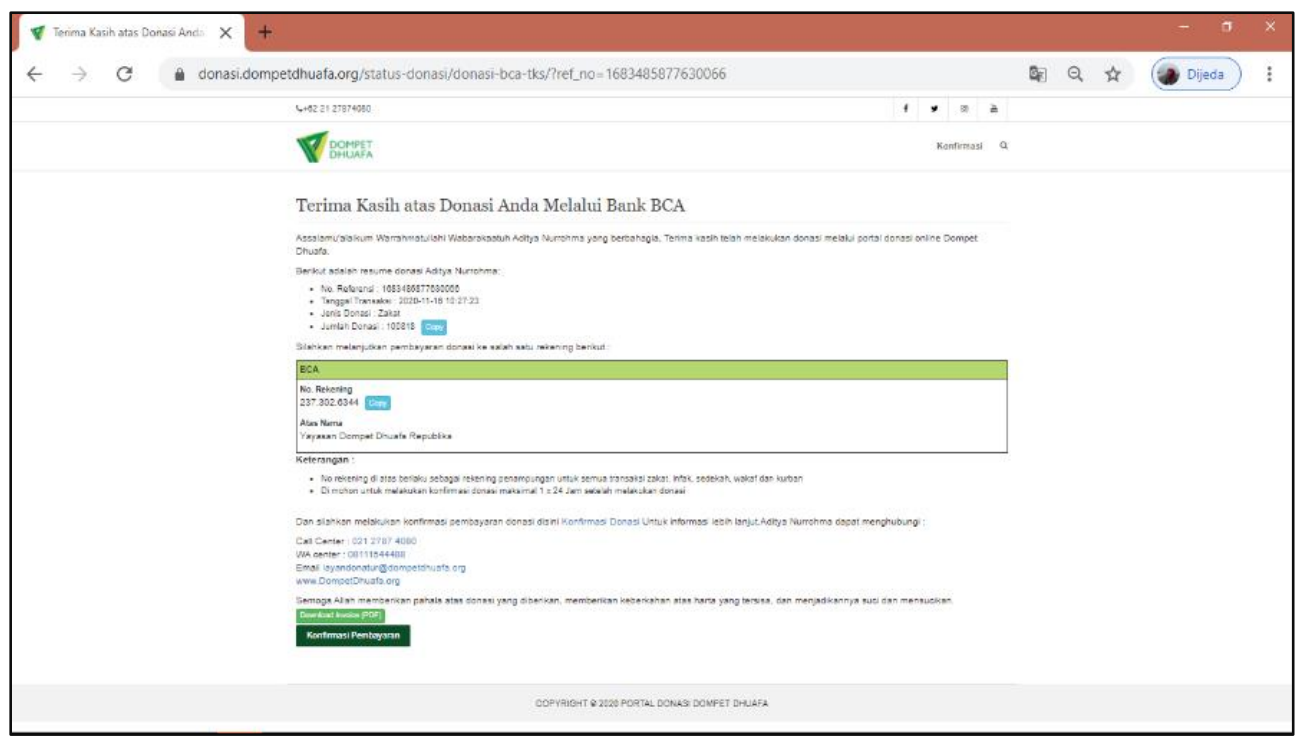

Gambar 3 - Layanan Pembayaran pada Website Dompet Dhuafa

Setelah muzaki mendapatkan penagihan terkait berapa jumlah yang harus dizakatkan, langkah berikutnya adalah melakukan pembayaran. Jika pembayaran merupakan metode-metode yang digunakan pelanggan untuk melakukan pembayaran sesuai yang disampaikan oleh Cristopher Lovelock pada teori the flower of service tentang layanan pembayaran, ${ }^{74}$ yang dalam konteks ini berarti metodemetode yang memudahkan muzaki dalam

73 Dompet Dhuafa, "Portal Donasi”, 16 September 2020, https://donasi.dompetdhuafa.org/. (diakses 16 September 2020). membayar zakat sehingga bisa melakukan pembayaran dengan cepat.

Pada website dompetdhufa.org, hanya terdapat metode-metode pembayaran yang mengharuskan muzaki keluar dari laman websitekarena hanya ada transfer bank atau online payment. Dimana metode pembayaran akan mengikuti pilihan muzaki pada kolom pemesanan.Misalnya ketika pada kolom pemesanan muzaki memilih

74 Lovelock, Pemasaran Jasa Manusia, Teknologi, Strategi, Jilid 1, Edisi ketujuh, 196. 
menggunakan metode transfer bank BCA, maka dalam melakukan pembayaran zakat perlu transfer menggunakan bank BCA. ${ }^{75}$ Kemudian ketika klik pilihan bayar maka akan muncul resume donasi, nomor rekening BCA yang beratas namakan Yayasan Dompet Dhuafa Republika, perintah untuk melakukan konfirmasi, dan nomor yang bisa dihubungi untuk melakukan konfirmasi. ${ }^{76}$ Sehingga meski muzaki diharuskan keluar dulu dari laman website dompetdhuafa.org,pada laman pembayaran muzaki akan ditunjukkan cara pembayaran, nomor rekening, maupun $Q R$ kode yang akan memudahkan muzaki ketika nantinya melakukan pembayaran zakat di luar website.

\section{Layanan Konsultasi}

Tampilan layanan konsultasi bisa dilihat pada gambar berikut: ${ }^{77}$

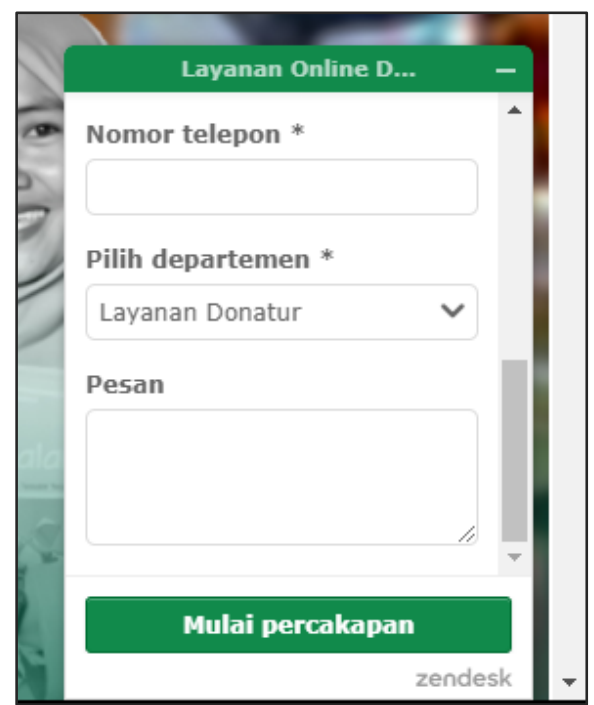

Gambar 4 - Layanan Konsultasi pada Webiste Dompet Dhuafa

${ }^{75}$ Dompet Dhuafa, "Portal Donasi", 16 September, https://donasi.dompetdhuafa.org/. (diakses 16 September 2020).

${ }^{76}$ Dompet Dhuafa, "Ringkasan-Donasi",16 September 2020, https://donasi.dompetdhuafa.org/ringkasandonasi/?RefNo=167806233935921. (diakses 16 September 2020).
Muzaki tetap bisa melakukan konsultasi meski tidak bertemu secara langsung dengan pihak lembaga. Jika melihatteori the flower of service dari Christopher Lovelock tentang layanan konsultasi yaitu sebuah layanan yang bisa memberikan jawaban bagi pelanggan yang membutuhkan saran, konseling, atau pelatihan untuk mendapatkan manfaat sebesar-besarnya. ${ }^{78}$ Dalam hal ini berarti layanan yang memberikan jawaban bagi muzaki yang membutuhkan saran, konseling, maupun pelatihan selama melakukan pembayaran zakat menggunakan website.

Maka kotak pertanyaan di kanan bawah yang berisi kesediaan Dompet Dhuafa melayani muzaki adalah bentuk layanan konsultasi yang disediakan oleh Dompet Dhuafa yang bisa dimanfaatkan secara online. Dengan begitu, meski muzaki tidak bertemu secara langsung dengan pihak lembaga namun tetap bisa menanyakan berbagai hal terkait penyaluran zakat pada Lembaga Dompet Dhuafa. ${ }^{79}$

Selain itu, saat muzaki membuka pilihan layanan, maka akan muncul beberapa pilihan salah satunya adalah FAQ. Ketika memilih pilihan $F A Q$, maka akan muncul pertanyaan-pertanyaan dari muzaki lain serta jawaban dari pihak Dompet Dhuafa. Sehingga muzaki juga bisa mengetahui pertanyaan-pertanyaan muzaki lain beserta jawabannya, dengan begitu bisa menambah pengetahuan ketika muzaki juga ternyata

\footnotetext{
77 Dompet Dhuafa, "Layanan Online Dompet Dhuafa", diakses 15 September 2020, https://v2.zopim.com/widget/livechat.html?api calls $=\% 5 \mathrm{~B} \% 5 \mathrm{D} \&$ hostname $=$ dompetdhuafa.org\&key $=2 \mathrm{Vyd}$ Z2LPaegCBdYRK6pmiwS6jcXxGFT\%Lang=id\&

78 Lovelock, Pemasaran Jasa Manusia, Teknologi, Strategi, Jilid 1, Edisi ketujuh, 197.

79 Dompet Dhuafa, "Layanan Online."
} 
ada kebingungan terhadap pertanyaan muzaki lain yang bisa jadi tidak disadari sebelumnya. Dimana data-data yang ditampilkan adalah pengetahuanpengetahuan umum seputar zakat. ${ }^{80}$

Kemudahan tersebut akan menjadikan muzaki tidak mengalami kebingungan selama mengakses website dompetdhuafa.org maupun ketika berzakat.Layanan konsultasi ini juga menjadi keuntungan bagi muzaki, karena tanpa bertemu namun tetap bisa terhubung dengan pihak Dompet Dhuafa dan bisa dibantu menjawab pertanyaan seputar zakat dengan online dan cepat. Apalagi layanan konsultasi ini tidak perlu keluar dari website sehingga mendukung kemudahan membayar zakat jika ada yang dibingungkan.

\section{Layanan Keramahan}

Tampilan layanan keramahan dapat dilihat pada gambar berikut: ${ }^{81}$

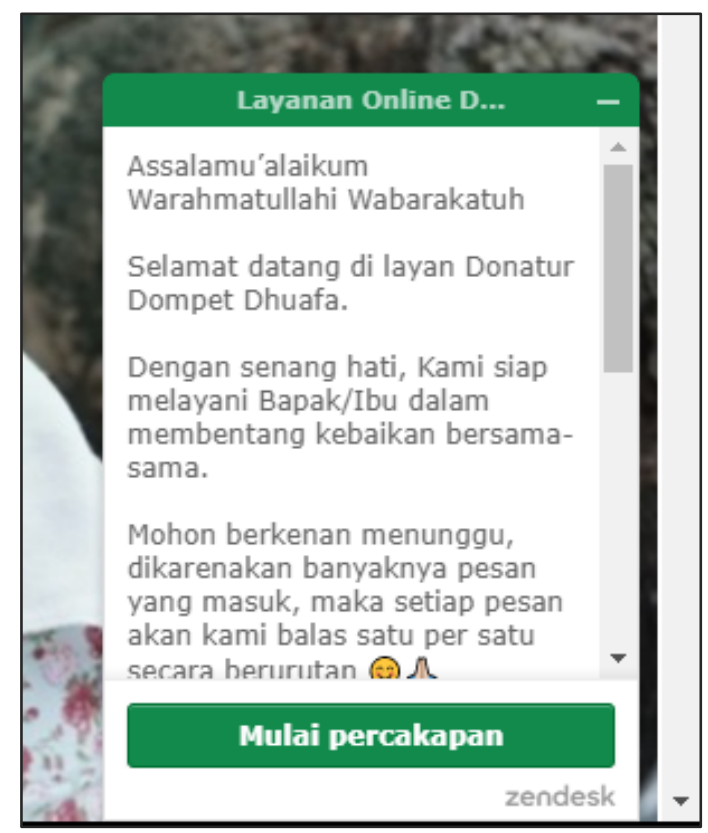

Gambar 5 - Layanan Keramahan pada Webiste Dompet Dhuafa

Meski tidak bertemu secara langsung, namun layanan keramahan tetap diperlukan pada layanan online. Menurut teori the flower of service yang disampaikan oleh Christopher Lovelock tentang layanan keramahan, bahwa layanan keramahan merupakan layanan yang memperlakukan para pelanggan seperti tamu dan menyediakan perlengkapan kenyamanan yang mampu mengantisipasi kebutuhan pelanggan selama berinteraksi dengan penyedia jasa dan menjadi layanan yang memperkuat produk inti, ${ }^{82}$ yang artinya dalam hal ini memperlakukan muzaki sebagai pengguna layanan zakat online sehingga perlu melayani sebaik mungkin

https://v2.zopim.com/widget/livechat.html?api calls $=\% 5 \mathrm{~B} \% 5 \mathrm{D} \&$ hostname $=$ dompetdhuafa.org\&key $=2 \mathrm{Vyd}$ Z2LPaegCBdYRK6pmiwS6jcXxGFT\%Lang=id\&

82 Lovelock, Pemasaran Jasa Manusia, Teknologi, Strategi, Jilid 1, Edisi ketujuh, 199. 
dan menyediakan perlengkapan kenyamanan untuk mengantisipasi kebutuhan muzaki selama mengakses layanan online untuk menyalurkan zakat.

Bentuk keramahan yang disediakan oleh Dompet Dhuafa bisa dilihat pada layanan konsultasi terdapat teks sambutan berupa "Assalamu'alaikum Warahmatullahi Wabarakatuh, selamat datang di layanan Donatur Dompet Dhuafa. Dengan senang hati, kami siap melayani Bapaklbu dalam membentang kebaikan bersama...." Hal tersebut menunjukkan bentuk sopan santunyang ditunjukkan seperti ketika bertemu langsung meski menggunakan bahasa teks. Sambutan pada layanan konsultasi ini yang disebut dengan layanan keramahan. $^{83}$

Bahkan bukan hanya pada layanan konsultasi namun pada layanan pemesanan juga terdapat layanan keramahan karena ketika muzaki hendak melakukan pemesanan untuk membayar zakat, akan ada sambutan berupa bahasa teks bawa muzaki sedang berada di portal donasi sehingga akan menjadikan muzaki merasa disambut ketika akan membayar zakat meski tidak bertemu secara langsung. ${ }^{84}$ Selanjutnya, pada layanan penagihan juga terdapat layanan keramahan yang ditunjukkan oleh Dompet Dhuafa, yaitu terkait ucapan terimakasih kepada muzaki

83 Dompet Dhuafa, "Layanan Online Dompet Dhuafa", 15 September 2020, https://v2.zopim.com/widget/livechat.html?api calls $=\% 5 \mathrm{~B} \% 5 \mathrm{D} \&$ hostname $=$ dompetdhuafa.org\&key $=2 \mathrm{Vyd}$ Z2LPaegCBdYRK6pmiwS6jcXxGFT\%Lang=id\&.

(diakses 15 September 2020).

84 Dompet Dhuafa, "Donasi", 15 September 2020, https://donasi.dompetdhuafa.org/. (diakses 15 September 2020).

${ }^{85}$ Dompet Dhuafa, "Ringkasan-Donasi", 16 September 2020,https://donasi.dompetdhuafa.org/ringkasan- yang sudah menunaikan zakat di Dompet Dhuafa. ${ }^{85}$

Pun pada layanan pembayaran juga terdapatbentuk keramahan berupa ucapan salam serta ucapan terimakasih atas donasi melalui metode pembayaran yang dipilih. Misalkan pada laman pemesanan memilih membayar menggunakan Bank BCA maka pada laman pembayaran akan ada ucapan terimakasih karena berdonasi melalui bank BCA. Selain ucapan terimakasih juga ada doa singkat yang diberikan untuk muzaki. ${ }^{86}$ Selain bentuk keramahan dengan menggunakan bahasa teks, bentuk keramaan lain yang bisa dijumpai oleh muzaki adalah kemudahan menggunakan website Dompet Dhuafa karena dalam laman website dompetdhuafa.org sudah ada pilihan-pilihan yang jika di klik akan langsung terhubung dengan hal-hal yang berkaitan dengan apa yang di pilih. Dengan begitu muzaki tidak perlu mengeluarkan banyak usaha selama mengakses website. ${ }^{87}$ Keseluruhan bentuk layanan tersebut dapat dikatakan sebagai layanan keramahan karena meski pada website namun pihak Dompet Dhuafa tetap berusaha menunjukkan bentuk keramahan dalam bahasa teks berupa ucapan salam, terima kasih, dan lain-lain seperti yang dijelaskan sebelumnya yang ditunjukkan kepada muzaki saat mengakses layanan zakat online.

donasi/?RefNo=167806233935921. $\quad$ (diakses 16 September 2020).

86 Dompet Dhuafa, "Terima Kasih atas Donasi Anda Melalui Bank BC", 19 Oktober 2020, https://donasi.dompetdhuafa.org/statusdonasi/donasi-bca-tks/?ref no $=1680990372756830$ (diakses 19 Oktober 2020).

87 Dompet Dhuafa, “Deskripsi Laman Depan”, 31 Desember 2020, http://www.dompetdhuafa.org/. (diakses 31 Desember 2020). 
Adanya layanan keramahan ini bisa menjadikan muzaki merasa nyaman ketika sedang mengakses website untuk menyalurkan zakat karena meski tidak bertemu secara langsung dengan pihak lembaga namun tetap ada sopan santun yang ditunjukkan dalam website. Sehingga layanan tersebut bisa makin mendukung produk inti terkait kemudahan menyalurkan zakat karena selama mengakses website, muzaki bisa merasakan sapaan yang diberikan pada website meski dalam bentuk teks ketika akan menyalurkan zakat hal tersebut juga menjadikan muzaki lebih nyaman selama mengakses website.

\section{Layanan Pengamanan}

Tampilan layanan pengamanan dapat dilihat pada gambar berikut: $: 8$

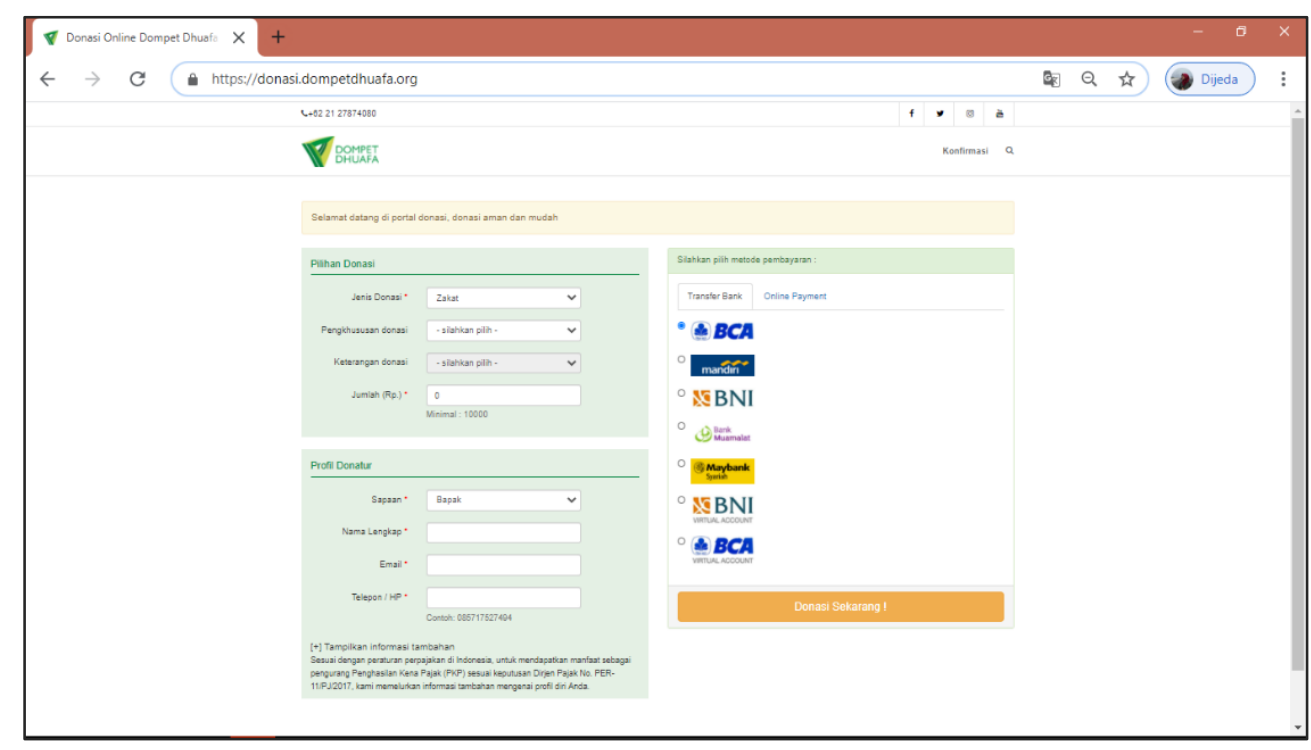

Gambar 6 - Layanan Pengamanan pada Webiste Dompet Dhuafa

Dalam rangka memperkuat produk inti, layanan pengamanan menjadi salah satu layanan yang diperlukan. Teori the flower of service dari Christoper Lovelock menjelaskan bahwa layanan pengamanan adalah layanan yang membantu pelanggan menangani atau mengamankan barang milik pribadinya, ${ }^{89}$ dalam konteks layanan zakatonline ini berarti layanan yang membantu muzaki dalam menangani atau mengamankan data-data milik muzaki yang

88 Dompet Dhuafa, "Alamat Website", diakses 15 September 2020, https://www.dompetdhuafa.org/ digunakan ketika mengakses layanan online.

Layanan keamanan yang disediakan Dompet Dhuafa bisa dilihat saat membuka website dompetdhuafa.org, padaalamat url-nya menggunakan awalan https (https://www.dompetdhuafa.org/) dan ada tanda gembok pada alamat website dompetdhuafa.org. Adanya tanda tersebut menunjukkan jika website

89 Lovelock, Pemasaran Jasa Manusia, Teknologi, Strategi, Jilid 1, Edisi ketujuh, 201. 
dompetdhuafa.org adalah website yang aman dan bisa diakses tanpa menjadikan data-data pribadi muzaki menjadi hilang. ${ }^{90}$

Adanya keamanan tersebut akan menjadikanmuzaki merasa aman ketika sedang mengakses layanan online dompetdhuafa.org untuk membayar zakat tanpa takut memasukan data yang bersifat privat, takut datanya hilang atau dicuri oleh pihak yang memiliki kepentingan karena kelebihan dari protokol https adalah dalam hal keamanan. ${ }^{91} \mathrm{Hal}$ tersebut juga diperkuat dengan salah satu indikasi website yang aman adalah menggunakan lapisan keamanan atau SSL (Secure Socket Layer), ${ }^{92}$ ciri dariwebsite yang ber-SSL yaitu url menggunakan https, pada samping kiri url terdapat greenbar yaitu terdapat gembok berwarna hijau. ${ }^{93}$

Sehingga adanya pengamanan pada website ini akan makin mendukung produk inti karena ketika muzaki tahu jika website yang digunakan aman maka akan menjadikan muzaki tidak ragu untuk menyalurkan zakat di lembaga tersebut, apalagi karena penyaluran zakat dilakukan secara online, maka indikasi situs yang aman menjadi prioritas utama supaya tidak mengalami hal-hal negatif seperti penipuan online dan lain sebagainya.

90 Dompet Dhuafa, "Alamat Website",15 September 2020, https://www.dompetdhuafa.org/. (diakses 15 September 2020).

91 Adzan Abdul Zabar dan Fahmi Novianto, "Keamanan http dan https Berbasis Web Menggunakan Sistem Operasi Kali Linux", Jurnal Ilmiah Komputer dan Informatika 04, no.02 (2015): 70-72.

92 Qwords, "Chrome Security Warning : Amaankan Website Sebelum Ditandai Tidak Aman", 23 September 2020, https://qwords.com/blog/chrome-

\section{Layanan Pengecualian}

Untuk mengetahui tampilan layanan pengecualian bisa dilihat pada gambar berikut. $^{94}$

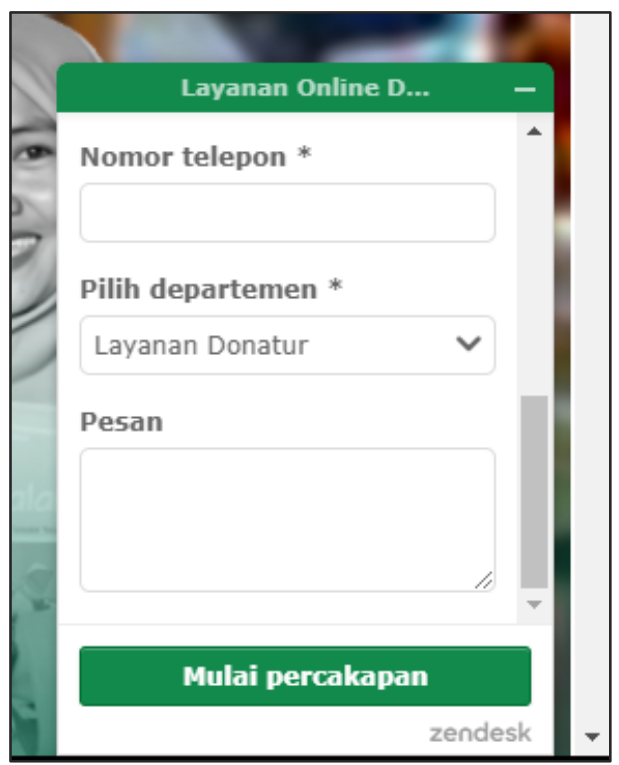

Gambar 7 - Layanan Pengecualian pada Webiste Dompet Dhuafa

Layanan pengecualian merupakan layanan yang memperkuat produk inti, yang bisa menanggapi permintaan khusus, pemecahan masalah, menangani pengaduan dan saran, dan menyediakan kompensasi ketika ada kegagalan produk. Hal tersebut diungkapkan oleh Christopher Lovelock dalam teori the flower of service. ${ }^{95}$ Maka dalam konteks ini, layanan pengecualiannya berupa fitur-fitur yang menanggapi permintaan khusus, memecahkan masalah, menangani

security-warning-amankan-website-sebelumditandai-tidak-aman/. (diakses 23 September 2020).

93 Ibid.,

94 Dompet Dhuafa, "Layanan Online Dompet Dhuafa", diakses 15 September 2020, https://v2.zopim.com/widget/livechat.html?api calls $=\% 5 \mathrm{~B} \% 5 \mathrm{D} \&$ hostname $=$ dompetdhuafa. org\&key $=2 \mathrm{Vyd}$ Z2LPaegCBdYRK6pmiwS6jcXxGFT\%Lang=id\&

95 Lovelock, Pemasaran Jasa Manusia, Teknologi, Strategi, Jilid 1, Edisi ketujuh, 203. 
pengaduan dan saran, serta menyediakan kompensasi atas kegagalan layanan zakat online terhadap muzaki.

Pada lembaga Dompet Dhuafa, layanan pengecualian bisa ditemukan pada kotak pertanyaan dibagian kanan bawah yang memiliki kesamaan dengan layanan konsultasi. Pada layanan pengecualian ini dimungkinkan setiap muzaki bisa menyampaikan atau mengungkapkan apapun didalam kotak pertanyaan tersebut. Saat diklik maka akan muncul kolom perkenalkan diri yang perlu diisi mulai dari nama dan email muzaki, lalu di bawahnya ada nomor telepon, pilih departemen, dan bagian paling bawah ada kolom untuk menuliskan pesan yang ingin ditanyakan. Kemudian klik mulai percakapan supaya pesan bisa terkirim. ${ }^{96}$

Hal tersebut bisa memudahkan muzaki ketika ingin menyampaikan hal-hal tertentu untuk direspon pihak Dompet Dhuafa. Adanya layanan pengecualian tersebut bisa menjadikan muzaki merasa terbantu karena ada layanan yang bisa menunjang kebutuhan muzaki jika ingin melakukan pengaduan, saran, maupun pujian kepada pihak Dompet Dhuafa secara cepat karena online.

\section{Kesimpulan}

Dari uraian penjelasan mengenai produk jasa Dompet Dhuafa yang menerapkan layanan zakat onlinemelalui website dompetdhuafa.org dengan menggunakan pendekatan teori the flower of service dari Christopher Lovelock, kesimpulannya

\footnotetext{
${ }^{96}$ Dompet Dhuafa, "Layanan Online Dompet Dhuafa", 15 September 2020,https://v2.zopim.com/widget/livechat.html?ap
}

adalah sebagai berikut: Pertama, Dompet Dhuafa memiliki produk inti pada layanan zakat online website dompetdhuafa.org berupa kemudahan bagi muzaki yang ingin menyalurkan zakat supaya tetap merasa aman dan menyalurkan zakat pada lembaga yang tepat di tengah pandemi Covid-19 karena muzaki tidak perlu bertemu secara langsung dengan pihak lembaga dan cukup menggunakan ponsel ketika akan menyalurkan zakat.

Kedua, pada website dompetdhuafa.org terdapat layanan tambahan yang bisa memudahkan muzaki dalam berzakat secara online dengan website dompetdhuafa.org, berupa informasi yang diberikan seputar pembayaran zakat serta berita-berita penyaluran zakat sampai sisipan nilai-nilai Islam sehingga menambah nilai manfaat untuk muzaki, adanya layanan pemesanan yang mudah dan efisien, kemudian muncul penagihan dengan nominal yang akurat, namun untuk melakukan pembayaran perlu keluar dari website.

Ketiga, selain layanan yang memudahkan, juga terdapat layanan yang menguatkan mulai dari layanan konsultasi berupa layanan chat yang bisa dijawab dengan cepat karena secara online, terdapat keramahan yang sopan berupa pesan teks yang bisa dijumpai pada website dan terdapat pada hampir setiap layanan meski muzaki dan petugas lembaga tidak bertemu secara langsung, pengamanan untuk memproteksi data diri muzaki, serta layanan pengecualian yang mudah di akses.

i calls $=\% 5 \mathrm{~B} \% 5 \mathrm{D}$ \&hostname=dompetdhuafa.org\&key =2VydZ2LPaegCBdYRK6pmiwS6jCXxGFT\%Lang=id\&. (diakses 15 September 2020). 
Sehingga penting bagi muzaki untuk menguasai penggunaan layanan zakat online pada website dompetdhuafa.org ini supaya muzaki tidak mengalami kesulitan ketika ingin menyalurkan zakat di masa pandemi dan bisa merasakan secara langsung terkait kemudahan menyalurkan zakat melalui website dompetdhuafa.org. apalagi dengan memahami setiap layanan yang ada pada website dompetdhufa.org mulai dari porduk inti sampai layanan tambahan yang akan makin memudahkan muzaki untuk menyalurkan zakat dengan aman dan pada lembaga yang tepat karena menyalurkan zakat pada yang berhak.
Untuk saran, studi ini harapannya bisa melengkapi khazanah ilmu manajemen dakwah serta referensi bagi lembaga amil zakat atau lembaga dakwah yang menghimpun dana berbasis donasi baik bersumber dari zakat maupun dana umat lainnya saat merumuskan produk jasa untuk mengetahui layanan zakat online apa saja yang sesuai di masa pandemi Covid-19 sehingga bisa memudahkan muzaki yang ingin menyalurkan zakatnya secara aman dan tepat serta tetap bisa merasakan manfaatnya meski menyalurkan zakat secara online.

\section{Bibliografi}

Bekti, Bintu Humairah. Mahir Membuat Website dengan Adobe Dreamwever CS6, CSS dan Jquery. Yogyakarta: Andi, 2015.

Djuanda, Gustian. Pelaporan Zakat Pengurang Pajak Penghasilan. Jakarta: PT Raja Grafindo Persada, 2006.

Fitriani, Eka Suci, Raden Agrosamhyo, dan Ely Mansur. "Strategi Penghimpunan dan Penyaluran Zakat, Infak, Sedekah (ZIS) Dalam Program Sebar Sembako Pada Masa Pandemi Covid-19 di Badan Amil Zakat Nasional (BAZNAS) Provinsi Bali". Jurnal IImu Pnedidikan dan Ekonomi Vol.5, no.9 (2020). https://journal.staidenpasar.ac.id/index.php/wb/article/view/52

Gunawan, Karebet. "Pelayanan Lembaga Zakat Untuk Meningkatkan Kepuasan Muzakki". Jurnal ZIZWAF 04, no.02 (2017). https://dx.doi.org/10.21043/ziswaf.v4i2.3047

Kamaruddin, Andi Martina, Zamruddin Hasid, dan Isna Yuningsih. "Faktor-Faktor yang Mempengaruhi Keputusan berzakat Profesi dan Loyalitas Muzakki terhadap LAZ Rumah Zakat Kota Samarida". Jurnal Eksekutive 12, no.2 (2015). https://jurnal.ibmt.ac.id/index.php/jeksekutif/article/download/97/96

Kotler dan Keller, Manajemen Pemasaran, Jilid 1, Edisi ke 13. Jakarta: Erlangga, 2009.

Lovelock, Christoper H. dan Lauren K. Wright, Manajemen Pemasaran Jasa.Jakarta: PT Macanan Jaya Cemerlang, 2005.

Lovelock, Christopher, Jochen Wirtz, dan Jacky Mussry, Pemasaran Jasa Manusia, Teknologi, Strategi, Jilid 1, Edisi ketujuh. Jakarta: Erlangga, 2010.

Nurislaminingsih, Rizki. "Layanan Pengetahuan Tentang Covid-19 di Lembaga Informasi". Jurnal Tik Ilmeu Vol.4, no.1 (2020). http://dx.doi/10.29240/tik.v4i1.1468

Pertiwi, Santika. "Produk Jasa Lembaga Daarul Quran Travel Haji dan Umrah Perspektif Pemasaran Jasa". Jurnal Pengembangan Ilmu Dakwah 02, no.01 (2020). http://www.inteleksia.stidalhadid.ac.id/index.php/inteleksia/article/download/65/40

Purhantara, Wahyu. Metode Penelitian untuk Bisnis. Yogyakarta: Graha Ilmu, 2010. 
Radhitya,Theresia Vania, Nunung Nurwati, dan Maulana Irfan, "Dampak Pandemi Covid-19 Terhadap Kekerasan Dalam Rumah Tangga". Jurnal Kolaborasi Resolusi Konflik Vo.2, no. 2 (2020). http://doi.org/10.24198/jkrk.v2i2.29119

Sakka, Abdul Rahman dan Latifatul Qulub. "Efektivitas Penerapan Zakat Online Terhadap Peningkatan Pembayaran Zakat pada Lembaga Dompet Dhuafa Sulses". Jurnal Ekonomi Islam 01, no.02 (2019). https://doi.org/10.37146/ajie.v1i2.21

Sanjaya, Yaya. Analisa Fungsi Anggaran Sebagai Alat Perencanaan dan Pengendalian terhadap Kinerja Keuangan Pengelolaan Dana (Studi pada Pengelolaan Dana di Dompet Dhuafa Jawa Barat). Tesis-Universitas Pendidikan Indonesia, Bandung, 2013. http://repository.upi.edu/13452/

Saputra, Andrika, Alvi Furwanti Alwie, dan Any Widayatsari. "Pengaruh Promosi dan Kualitas Pelayanan Terhadap Kepercayaan dan loyalitas Donatur Dompet Dhuafa Riau". Jurnal Dakwah Risalah 31, no.01 (2020). https://dx.doi.org/10.24014/jdr.v31i1.10040

Sugiyono. Metode Penelitian Kuantitatif, Kualitatif, dan R\&D. Bandung: CV Alvabeta, 2017.

Sutio, Muhammad. "Pengaruh Tingkatan Produk Terhadap Loyalitas Pelanggan. Jurnal Digest Marketing 03, no.01 (2018). https://doi.org/10.22437/imk.v6i2.4049

Sutomo, Mukhamad Najid dan Setiadi Djohar. "Pengaruh Kualits Pelayanan Lembaga Amil Zakat (LAZ) Terhadap Kepuasan dan Loyalitas Muzakki (Studi Kasus LAZ PKPU Yoyakarta)". Jurnal Aplikasi Bisnis dan Manajemen 03, no.01 (2017). https://journal.ipb.ac.id/index.php/jabm/article/view/14875

Sutomo, Mukhamad Najid dan Setiadi Djohar. "Pengaruh Kualitas Pelayanan Lembaga Amil Zakat (LAZ) Terhadap Kepuasan dan Loyalitas Muzakki (Studi Kasus LAZ PKPU Yoyakarta)". Jurnal Aplikasi Bisnis dan Manajemen 03, no.01 (2017). https://doi.org/10.17358/iabm.31.59

Tjiptono, Fandy. Strategi Pemasaran, Edisi 4. Yogyakarta: Andi, 2015.

Wirtz, Jochen dan Christopher Lovelock. Service Marketing: People, Technology, Strategy. USA : Pearson Education, 2016.

Zabar, Adzan Abdul dan Fahmi Novianto. "Keamanan http dan https Berbasis Web Menggunakan Sistem Operasi Kali Linux". Jurnal IImiah Komputer dan Informatika 04, no.02 (2015). http://komputa.if.unikom.ac.id/jurnal/keamanan-http-dan-https.2b 